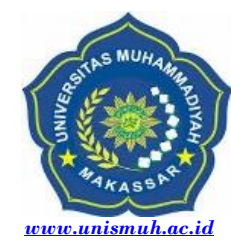

\title{
Penerapan Nilai-nilai Pancasila dalam Mencegah Kenakalan Remaja di Sekolah Menengah Atas Negeri 1 Enrekang
}

\author{
Rismawati $^{1)}$, A Rahim $^{2)}$, \& Jumiati Nur ${ }^{3)}$ \\ Sekolah Menengah Atas Negeri 1 Kabupaten Enrekang Indonesia ${ }^{1)}$ \\ Program Studi Pendidikan Pancasila dan Kewarganegaraan FKIP Universitas Muhammadiyah Makassar Indonesia 2,3$)$ \\ rismawati@gmail.com ${ }^{11}$,arahim@unismuh.ac.id ${ }^{21}$ _jumiatinur@unismuh.ac.id $d^{3)}$
}

\begin{abstract}
The problem in this research is the application of Pancasila Values in the prevention of juvenile delinquency in Enrekang 1 High School. The type of research used is descriptive Qualitative which is carried out in SMA 1 Enrekang. Informants in this study were the school principal, PPKn teacher and students. Collection techniques use observation, interviews and documentation. Data analysis techniques used descriptive analysis. The results of the research analysis showed that the application of Pancasila Values in the prevention of juvenile delinquency in Enrekang $1 \mathrm{High}$ School was carried out by practicing the Pancasila Values towards students. Application of Precepts I (Saying greetings in every daily activity, praying before and after teaching and learning activities, prayer in congregation), Precepts II (Attitudes of mutual assistance between each other, Recognizing rights and obligations agreements), Precepts III of the Indonesian Nation), Precepts IV (approves freedom of conveying development, completes everything by deliberation and consensus), Sila V (Supports fair tolerance for all students). Supporting factors in combating juvenile delinquency in SMA Negeri 1 Enrekang come from school principals, teachers, students and facilities and supporters which supports social relationships and student mindset. The inhibiting factor in the prevention of juvenile delinquency in Enrekang 1 High School is the limited time allocation providing guidance and guidance of teacher education to the teacher's advice.
\end{abstract}

Keywords: Pancasila Values, Delinquency, Teenagers

\begin{abstract}
Abstrak. Permasalahan dalam penelitian ini adalah penerapan Nilai-nilai Pancasila dalam mencegah kenakalan remaja di SMA Negeri 1 Enrekang. Jenis penelitian yang digunakan adalah deskriptif kualitatif yang dilaksanakan di SMA Negeri 1 Enrekang. Informan dalam penelitian ini adalah Kepala sekolah, Guru PPKn dan siswa. Tehnik pengumpulan menggunakan observasi, wawancara dan dokumentasi. Tehnik analisis data menggunakan analisis deskriptif. Hasil analisis penelitian menunjukkan bahwa Penerapan Nilai-nilai Pancasila dalam mencegah kenakalan remaja di SMA Negeri 1 Enrekang dilakukan dengan pengamalan Nilai-nilai Pancasila terhadap siswa. Penerapan Sila I (Mengucapkan salam dalam setiap kegiatan sehari-hari, berdo'a sebelum dan sesudah kegiatan belajar mengajar, sholat berjamaah), Sila II (Sikap saling membantu antar sesama, Mengakui persamaan hak dan kewajiban), Sila III (Memiliki rasa bangga menjadi bangsa Indonesia), Sila IV (Memberikan kebebasan menyampaikan usul membangun, menyelesaikan segala sesuatu dengan musyawarah dan mufakat), Sila $V$ (Memiliki sikap adil kepada seluruh siswa).Faktor pendukung dalam mencegah kenakalan remaja di SMA Negeri 1 Enrekang datang dari Kepala sekolah, Guru, siswa serta sarana dan pra sarana yang mendukung dan adanya hubungan sosial serta pola pikir siswa. Faktor penghambat dalam mencegah kenakalan remaja di SMA Negeri 1 Enrekang adalah Keterbatasan alokasi waktu memberikan pembinaan dan bimbingan Guru Pendidikan kewarganegaraan dalam mengajar menggunakan alokasi dua jam mata pelajaran, Pergaulan teman sebaya, Orangtua peserta didik tidak memenuhi panggilan dari pihak sekolah, dan sikap masa bodoh peserta didik terhadap nasihat guru.
\end{abstract}

Kata kunci: Nilai Pancasila, Kenakalan, Remaja 


\section{PENDAHULUAN}

Kenakalan siswa akhir-akhir ini sering terjadi di lingkungan sekolah, sebagai akibat tidak disiplinnya penerapan tata tertib sekolah yang belum dipahami oleh siswa dari latar belakang lingkungan pedesaan maupun letak sekolah yang merupakan masuk dalam kategori daerah pedesaan terpencil, sehingga muncul berbagai tindakan pelanggaran terhadap tata tertib sekolah meskipun gejala yang ditimbulkan tidak terlalu signifikan dengan pelanggaran- pelanggaran tata tertib yang dilakukan oleh siswa yang bertempat tinggal diperkotaan. Namun kecenderungan untuk melakukan pelanggaran tata tertib sekolah merupakan tanda adanya kemerosotan nilai moral sebagai dampak negatif pesatnya arus globalisasi di Indonesia saat ini. Sehingga siswa berusaha untuk meniru dan mencontoh tindakan-tindakan yang ada di berbagai media sebagai bentuk pancarian indentitas diri seorang siswa dalam usia remaja agar diakui dan diterima dalam kelompoknya.

Adapun bentuk-bentuk kenakalan remaja yang terjadi pada siswa mulai dari yang kekerasan verbal (penyampaian kata-kata), kekerasan fisik, hingga tindakan asusila seperti penghinaan hingga pelanggaran-pelanggaran terhadap tata tertib disekolah juga bisa diindikasikan sebagai bentuk kenakalan remaja yang sedang mengalami masa yang penuh kegairahan yang tinggi namun diekspresikan dalam bentuk yang negatif dalam rangka mencari identitas diri sebagai manusia.

Permasalahan yang sering terjadi pada siswa di usia remaja berkaitan dengan masamasa pertumbuhan dan perkembangan remaja yang berubah dari masa anak-anak. Pada masa remaja adalah masa penuh warna dan dinamika, disertai rangkaian gejolak emosi yang menghiasi perjalanan seorang manusia yang hendak bertumbuh dewasa. Pada masa remajalah seorang manusia mulai membangun jati diri, memiliki kehendak bebas (freewill untuk memilih), memegang teguh prinsip, dan mengembangkan kapasitasnya.

Peralihan suatu masa pertumbuhan dan perkembangan seorang siswa dari masa anak-anak menuju masa remaja tersebut ditemukan banyak kasus pada kehidupan sehari-hari yang diawali dari tontonan dan perilaku tindakan kekerasan dimedia dapat berdampak secara langsung maupun tidak langsung pada perilaku anak-anak terutama para siswa disekolah dengan mengimitasi budaya atau perilaku kekerasan secara kolektif maupun secara individu.

Ragam persoalan kekerasan yang masuk dalam kategori kenakalan siswa dalam usia remaja tersebut dapat dilihat dari pertumbuhan dan perkembangan remaja pada usia sekolah menengah atas (SMA).

Siswa dari sekolah menengah atas yang dikategorikan dalam remaja yang sedang belajar mengalami pergolakan-pergolakan fisik dan psikologi yang dilihat dari pertumbuhan secara fisik dan perkembangan secara psikologi. Dalam Asmani (2011: 13) menjelaskan bahwa masa yang paling bergolak dalam kehidupan manusia adalah masa remaja. Masa ini berlangsung dari usia 12 tahun sampai 18-20 tahun (yaitu usia sekolah menengah), dimana seorang anak mulai mengalami transformasi dari anak-anak menjadi manusia dewasa. Masa ini juga menjadi masa di mana remaja belajar dan berkembang dalam mengenali diri dan lingkungan sekitarnya.

Persoalan tentang kenakalan siswa sering diidentikkan dengan tindakan kekerasan dikalangan siswa, untuk itulah pembekalan dan pemahaman tentang tindakan kekerasan juga masih belum dimengerti oleh para siswa. Persepsi tentang tindakan kekerasan dikalangan siswa bermula masih terfokus pada pengertian dan persepsi atau bahkan perspektif (sudut pandang) yang berbeda-beda dalam mengartikan tindakan kekerasan. Sebagian siswa mengartikan tindakan kekerasan sebagai tindakan yang menggunakan paksaan untuk mewujudkan niat seseorang atau sekelompok orang, serta dorongan untuk melukai siswa yang lainnya demi membela keyakinan dan atau kekerasan lain yang melibatkan fisik seseorang. Juga persepsi yang akan terbayang tentang tindakan kekerasan yang sering dikaitkan dengan tawuran atau perkelahian massal antar siswa. Sesuai dengan pandangan Martono (2012: 
1) mengemukakan bahwa ketika kita mendengar kata "kekerasan", sebagian diantara kita akan mengarahkannya pada sebuah peristiwa yang mengerikan, menakutkan, atau bahkan mematikan. Kekerasan juga dinilai sebagai sebuah tindakan yang melanggar HAM (Hak Asasi Manusia), suatu konsep yang menjadi fokus perhatian di berbagai forum diskusi. Fenomena kekerasan saat ini telah mewarnai hampir seluruh aspek kehidupan sosial kita baik politik, budaya, bahkan hingga pendidikan.

Persepsi tindakan kekerasan tersebut menggambarkan bahwa tindakan kekerasan juga berkaitan kenakalan remaja baik lingkungan masyarakat ataupun sekolah secara khusus di lingkungan kelas siswa yang masuk dalam kategori pelanggaran pelanggaran tata tertib sekolah. Sehingga tidak mengherankan ketika akan mengkaji dan mendalami fenomena tindakan kekerasan, maka definisi dan persepsi orang menghindari kajian tentang tindakan kekerasan bahkan akan melakukan penolakan baik dalam bentuk pendapat, persepsi maupun analisa tentang tindakan kekerasan. Padahal tindakan kekerasan sebenarnya tidak hanya berupa fisik, melainkan bisa berbentuk simbol-simbol tertentu dalam artian yang lain, seperti kekerasan simbolik termasuk pelanggaran tata tertib sekolah.

Pada penelitian ini siswa yang dijadikan subyek penelitian merupakan siswa masuk dalam kategori siswa yang nakal dan sering melakukan tindakan kekerasan yang terjadi di kelas, terutama kelas XI SMA Negeri 1 Enrekang, dimana siswa yang berada di kelas XI tersebut termasuk dalam kategori remaja awal, sebab secara biologis siswa yang melakukan tindakan kekerasan tersebut bisa dikategorikan ke dalam batasan usia remaja awal yang sedang menuntut ilmu di SMA rata-rata berusia berkisar 14-15 tahun.

Menurut Asmani (2012:41), mengungkapkan bahwa batasan usia remaja yang umumnya digunakan para ahli adalah antara 12 hingga 21 tahun. Rentang waktu usia remaja ini biasanya dibedakan atas tiga tahapan, yaitu masa remaja awal (12-15 tahun), masa remaja pertengahan (15-18 tahun), dan masa remaja akhir (18-21 tahun).

Menurut sumber dari guru Bimbingan Konseling (BK), kasus kekerasan simbolik dikelas dapat dilihat dari bentuk-bentuk kenakalan remaja yang mengarah pada pelanggaran tata tertib sekolah yang berdasarkan data menunjukkan bahwa tingkat pelanggaran siswa diantara kelas XI hingga kelas XII, yang termasuk kategori sangat sering melakukan pelanggaran tata tertib sekolah adalah kelas XI terutama rombongan belajar (rombel) kelas XI SMA Negeri 1 Enrekang. Lebih lanjut beliau mengatakan bahwa selama satu semester berjalan pada tahun pelajaran 2017/2018, kejadian pelanggaran siswa terhadap tata tertib sekolah yang sangat menonjol adalah kelas XI yang secara emosional para siswa dalam menyelesaikan masalah terkadang tidak menggunakan cara-cara damai dan dialog dan lebih mengedepankan prilaku kekerasan secara fisik menjadi kebiasaan dalam menyelesaikan masalah, ini belum lagi apabila terjadi keterlibatan siswa dalam situasi kekerasan massa yang pada akhirnya siswa akan menjadi korban secara fisik maupun psikis yang berkepanjangan akibat muncul trauma pada diri siswa terutama kelas XI SMA Negeri 1 Enrekang.

Peran pemerintah dalam menangani tindakan kekerasan dikalangan siswa diperlukan peraturan-peraturan perundang-undangan secara tegas untuk melindungi siswa dari tindakan kekerasan. Penanganan tindakan kekerasan oleh pemerintah tertuang dalam Undang-Undang No. 23 Tahun 2002, tentang perlindungan anak.

Undang-Undang No. 23 Tahun 2002 Tentang Perlindungan Anak Pada pasal 59 menyatakan bahwa pemerintah dan lembaga Negara lainnya berkewajiban dan bertanggung jawab untuk memberikan perlindungan khusus kepada anak dalam situasi darurat, anak yang berhadapan hukum, anak dari kelompok minoritas dan terisolasi, anak tereksploitasi secara ekonomi dan/atau seksual, anak yang diperdagangkan, anak yang menjadi korban penyalahgunaan narkotika, alkohol psikotropika dan zat adiktif lainnya (napza), anak korban penculikan, penjualan dan 
perdagangan, anak korban kekerasan baik fisik dan/atau mental, dan anak korban perlakuan salah dan penelantara.

Pada pasal 69 ayat (2) menyatakan bahwa Setiap orang dilarang menempatkan, membiarkan, melakukan, menyuruh melakukan, atau turut serta melakukan kekerasan sebagaimana dimaksud dalam pasal (1). Sedangkan siswa yang dilindungi dari tindakan kekerasan disekolah sesuai pada pasal 54 UU No. 23 tahun 2002 bahwa: Anak di dalam dan di lingkungan sekolah wajib dilindungi dari tindakan kekerasan yang dilakukan oleh guru, pengelola sekolah atau teman- temannya di dalam sekolah yang bersangkutan, atau lembaga pendidikan lainnya.

Meskipun pihak pemerintah sudah mengeluarkan undang-undang yang mengatur tentang perlindungan anak, menunjukkan bahwa Indonesia belum dapat melepaskan diri dari persoalan dekadensi moral, berupa merosotnya komitmen masyarakat dalam berbagai lapisan terhadap etika kehidupan masyarakat dan berbangsa serta bernegara. Fenomena lain yang sedang menggejala saat ini adalah perilakun yang tidak santun, penghinaan, perilaku, kekerasan, penyalahgunaan kekuasaan, merokok, membolos dan mencorat-coret dinding sekolah merupakan bentuk-bentuk pelanggaran tata tertib di sekolah.

Hingga saat ini sebenarnya banyak dikalangan siswa dengan mudahnya berinteraksi dengan kondisi-kondisi sosial yang bertentangan dengan nilai-nilai moral, sebagai akibat dari dampak negatif arus globalisasi yang sangat pesat akhir-akhir ini, kejadian tersebut sebagai akibat interaksi sosialnya yang sudah sedemikian terbuka tanpa mengenal batas dan tempat.

Segala bentuk kekerasan tersebut, kini semakin marak terjadi di Indonesia, baik di keluarga, sekolah, masyarakat dan juga di level negara. Kekerasan itu bisa terjadi kapan saja dan dilakukan oleh siapa saja. Terkadang, secara sengaja maupun tidak sengaja perilaku yang yang menyimpang bisa dikatakan sebagai tindak kekerasan terhadap seseorang.
Dampak negatif tersebut antara lain semakin maraknya berbagai penyimpangan norma kehidupan agama dan sosial kemasyarakatan yang terwujud dalam bentuk kenakalan siswa di sekolah seperti: sikap tidak menghormati kepada guru dan karyawan, perilaku ini tampak dalam hubungan siswa dengan guru atau karyawan di mana siswa sering acuh tak acuh terhadap keberadaan guru dan karyawan sekolah, kurang disiplin terhadap waktu dan tidak mengindahkan

peraturan. Siswa masih sering terlambat masuk kelas, membolos, tidak memakai seragam dengan lengkap, dan menggunakan model baju yang tidak sesuai ketentuan sekolah dan membawa senjata tajam, perilaku kurang memelihara keindahan dan kebersihan lingkungan tampak dengan adanya perbuatan mencorat- coret dinding sekolah atau kelas, merusak tanaman, dan membuang sampah seenaknya, perkelahian antar siswa, sering terjadi perkelahian antar siswa satu sekolah bahkan perkelahian antar sekolah, merokok di sekolah pada jam istirahat, berbuat asusila, seperti adanya siswa putra yang mengganggu siswa putri dan melakukan perbuatan asusila di lingkungan sekolah.

Kenakalan siswa yang dapat dikatakan sebagai bentuk kekerasan disekolah, pencegahannya sering dilakukan dengan pendekatan kedisiplinan. Menurut Martono (2012: 1) mengemukakan bahwa kekerasan atau bullying di sekolah, sering dilegitimasi dengan alasan "menegakkan disiplin" di kalangan siswa atau mahasiswa misalnya kekerasan yang dilakukan guru karena siswa tidak mengerjakan PR, ribut dikelas dan bolos serta kekerasan yang dilakukan sesama siswa saat ospek.

Selain alasan menegakkan disiplin juga dapat terjadi karena motif menunjukkan rasa solidaritas, proses pencarian jati diri, serta kemungkinan adanya gangguan psikologis dalam diri siswa. Misalnya, tawuran antarpelajar yang dapat dilatarbelakangi karena siswa merasa menjadi satu golongan yang membela "teman" atau "membela sekolahnya".

Lebih lanjut konsep tentang „kekerasan simbolik" dikemukakan oleh Pierre Bourdieu, 
seorang sosiolog dari Perancis. Bourdieu menggunakan konsepini untuk menjelaskan mekanisme yang digunakan kelompok kelas atas yang mendominasi struktur sosial masyarakat untuk "memaksakan" ideologi, budaya, kebiasaan, atau gaya hidupnya kepada kelompok kelas bawah yang dodominasinya. Rangkaian budaya ini oleh Bourdieu disebut juga sebagai habitus. Akibatnya masyarakat kelas bawah, dipaksa untuk menerima, menjalani, mempraktikan, dan mengakui bahwa habitus kelas atas merupakan habitus yang pantas bagi mereka (kelas bawah), sedangkan habitus kelas bawah merupakan habitus yang sudahselayaknya "dibuang jauh-jauh". Nilainilai yang ditanamkan kepada siswa harus semakin diperdalam dengan cara memperkenalkan mengapa nilai-nilai itu ditanamkan. Tahap demi tahap mulai dikembangkan unsur pemahaman kepada diri siswa, nilai-nilai kejujuran, keadilan, kepahlawanan harus sudah mulai diperkenalkan dan harus mendapat tekanan serta perhatian.

Ditinjau dari usia remaja, usia tersebut merupakan usia sekolah bagi anak. Di lingkungan sekolah posisi remaja adalah sebagai siswa, jadi kenakalan remaja yang dilakukan oleh siswa dapat disebut sebagai kenakalan siswa. Dengan demikian kenakalan siswa merupakan penyimpangan perilaku siswa yang berakibat siswa melanggar aturan atau tata tertib sekolah.

Sebuah lembaga pendidikan memiliki fungsi yang sangat strategis dalam mengembangkan sebuah penciptaan lingkungan sekolah yang menghargai kultur yang hormat terhadap nilai-nilai moral. Sekolah bisa menjadi kesempatan yang baik untuk membuktikan kinerja dan integritas profesional mereka sehingga mereka mampu memposisikan diri sebagai model bagi keteladanan siswa.

Berdasarkan informasi yang diperoleh dari wakil kepala sekolah SMA Negeri 1 Enrekang bidang kesiswaan, ditemukan beberapa kasus pelanggaran siswa terhadap tata tertib sekolah, seperti: membolos, berkelahi, merokok, cara berpakaian, tidak melaksanakan upacara hingga pada penghinaan terhadap guru dan sesama siswa

\section{METODE PENELITIAN}

Jenis penelitian ini adalah penelitian kualitatif deskriptif. Metode penelitian kualitatif adalah metode penelitian yang berlandaskan pada filsafat postpositivisme, digunakan untuk meneliti pada kondisi obyek yang alamiah.

Teknik pendekatan yang digunakan dalam penelitian ini adalah teknik pendekatan sosiologis yaitu mempelajari/mendekati subjek penelitian tentang penerapan nilai-nilai pancasila dalam mencegah terjadinya kenakalan remaja di SMA Negeri 1 Enrekanga kondisi obyek yang alamiah.

Lokasi penelitian di SMA Negeri 1 Enrekang, kegiatan penelitian ini dilaksanakan pada Tanggal 16 Juli-9 Agustus 2018. Subjek penelitian adalah siswa Negeri 1 Enrekang, guru PPKn SMA Negeri 1 Enrekang, dan Kepala sekolah SMA Negeri 1 Enrekang. Adapun prosedur pelaksanaan penelitian yang akan dilakukan mulai mengumpulkan data, mengelola data, menganalisis data sampai menarik kesimpulan.

Adapun tehnik pengumpulan data dalam penelitian ini adalah observasi, wawancara, dan dokumentasi. Analisis data dalam penelitian ini adalah (a) Pengumpulan data dalam penelitian ini dilakukan dengan berbagai cara seperti observasi, wawancara dan dokumentasi. Data dicatat secara objektif dan sesuai dengan kenyataan yang ada di lapangan Data yang dikumpulkan berkaitan dengan penerapan nilai-nilai pancasila dalam mencegah terjadinya kenakalan remaja di SMA Negeri 1 Enrekang. (b) Reduksi data, data yang diperoleh peneliti dipilih mana yang penting dan yang tidak perlu digunakan dalam penelitian ini. Peneliti akan memilih hal-hal pokok, memfokuskan pada hal-hal yang penting, dan membuang yang tidak perlu, (c) Penyajian data yang diperoleh dari tahap reduksi data maka data selanjutnya disajikan dan dibandingkan dengan kajian teori yang telah dibuat, (d) Penarikan kesimpulan dan verifikasi yang dapat menjawab fokus masalah atau rumusan masalah dalam penelitian ini.

\section{PEMBAHASAN}

Pancasila mengandung nilai-nilai yang hakiki, yang di dalam Pembukaan Undang-undang Dasar 
1945 diberi kedudukan sebagai dasar negara. Dasar Negara tidak akan mempunyai makna jika kita sebagai pendukungnya tidak mampu untuk melaksanakannya atau mengamalkannya dalam kehidupan sehari-hari.

Di masa sekarang ini, nilai-nilai luhur Pancasila tampaknya sudah banyak ditinggalkan. Banyak sekali terjadi penyimpangan-penyimpangan yang terjadi di mana-mana. Hal ini tentu sangatlah mengkhawatirkan di mana Pancasila sudah tidak menjadi sesuatu yang dianggap penting. Pancasila sebagai sumber dari segala sumber hukum yang berlaku di Indonesia, memiliki nilai-nilai yang terkandung di dalamnya yang telah dijelaskan dalam Pembukaan UUD 1945. Tanpa Pancasila, masyarakat nasional kita tidak akan pernah mencapai kekukuhan seperti yang kita miliki sekarang ini.

Pada dasarnya Pancasila sudah ada dan sudah diamalkan tetapi masih dirasa pengamalannya kurang merata. Itulah sebabnya ada bermacam-macam usaha untuk lebih menghayati dan mengamalkan Pancasila, sehingga pengamalannya membudaya, menjadi satu dengan kebiasaan dan kehidupan sehari-hari. Dengan demikian dapatlah disebut bahwa Pancasila sudah dapat mendarah daging ke dalam tubuh manusia.

Dari hasil penelitian terhadap informan baik dari kepala sekolah, guru PPKn, dan siswa di SMA Negeri 1 Enrekang maka diperoleh informasi dan pembahasan tentang penerapan Nilai-nilai Pancasila dalam mencegah kenakalan remaja di SMA Negeri 1 Enrekang.

Berdasarkan hasil penelitian, SMA Negeri 1 Bajeng sudah berupaya menerapkan nilai-nilai Pancasila dari sila I sampai dengan sila ke $V$ dalam mencegah kenakalan remaja. Penerapan nilai-nilai Pancasila juga dicerminkan dari hubungan keseharian antar siswa. Menerapkan nilai-nilai Pancasila sepertinya tidak sulit dilakukan oleh siswa dalam mencegah kenakalan remaja.

Kegiatan-kegiatan yang dilakukan oleh siswa di dalamnya mengandung nilai-nilai Pancasila yang merupakan jiwa luhur bangsa Indonesia, kemudian diamalkan mahasiswa baik dalam berhubungan dengan sesama anggota maupun dalam kehidupan sehari-hari, sebagai kepribadiaan hidup. Nilai-nilai tersebut kemudian diyakini kebenarannya sebagai pandangan hidup dalam bermasyarakat.

Sila I yaitu (Ketuhanan yang Maha Esa). Sejak zaman dahulu masyarakat Indonesia tidak pernah putus-putusnya percaya kepada Tuhan. Sila pertama ini mengandung nilai-nilai yang menjiwai keempat sila lainnya. Negara didirikan sebagai penjawantahan tujuan manusia sebagai makhluk Tuhan Yang Maha Esa. Dalam kegiatan bernegara berdasarkan Pancasila, maka negara menjamin hakhak warga negara untuk dapat menjalankan keyakinan yang dianutnya.

Berdasarkan hasil penelitian, penerapanNilainilai Pancasila sila I (Ketuhanan yang Maha Esa) diterapkan di SMA Negeri 1 Enrekang dalam mencegah kenakalan remaja dengan membiasakan budaya pengucapan salam sebelum memulai atau menutup kegiatan proses belajar mengajar kemudian melakukan do'a bersama didalam isasikegiatan proses belajar mengajar. Selain itu kegiatan siswa dihentikan sejenak pada saat waktu sholat hendak dilaksanakan. Hal ini juga sejalan dengan kaedah penerapannilai-nilai Pancasila sila I (Ketuhanan yang Maha Esa) menurut Ketut Rindjin (2012, 192-193) yaitu sembahyang, berdoa, membaca buku suci, berguru pada tokoh agama, serta mempunyai toleransi agama/ kepercayaan kepada Tuhan Yang Maha Esa.

Berdasarkan hasil penelitian dan kajian teori dapat disimpulkan bahwa penerapan Nilai-nilai Pancasila sila I (Ketuhanan yang Maha Esa) dalam mencegah kenakalan remaja di SMA Negeri 1 Enrekang dilakukan dengan membiasakan diri mengucapakan salam, berdoa, dan sholat.

Sila ke II (Kemanusiaan yang Adil dan Beradab) yang dilaksanakan dalam mencegah kenakalan remaja juga mengandung nilai-nilai yang akan dicapai yaitu merupakan kegiatan kemanusiaan, menghargai perbedaan suku, ras, kedudukan sosial serta mengakui persamaan hak dan kewajiban sesama manusia.

Berdasarkan hasil penelitian, penerapan Nilai-nilai Pancasila sila II (Kemanusiaan yang Adil dan Beradab) dalam mencegah kenakalan remaja yaitu mengakui persamaan hak dan kewajiban di 
antara sesama siswa, tidak ada pemaksaan guru kepada siswa untuk menyampaikan pendapat serta tetap saling menghargai dan menghormati walaupun berbeda suku, gender, ras, dan sebagainya.

Hal ini sejalan dengan Darmadiharjo (1996) dalam Kaelan (2010: 81) bahwa konsekuensi nilai yang terkandung dalam sila II (Kemanusiaan Yang Adil dan Beradab) adalah menjunjung tinggi harkat dan martabat manusia sebagai makhluk Tuhan, menjunjung tinggi hak asasi manusia, menghargai kesamaan hak dan derajat tanpa membedakan suku, agama, ras keturunan, dan status sosial. Mengembangkan sikap saling mencintai sesama manusia, saling meghormati, serta menjunjung tinggi nilai-nilai kemanusiaan.

Berdasarkan hasil penelitian dan kajian teori dapat disimpulkan,penerapan Nilai-nilai Pancasila sila II (Kemanusiaan yang adil dan beradab) dalam mencegah kenakalan remaja di SMA Negeri 1 Enrekang yaitu adanya sikap saling membantu, mengakui persamaan hak dan kewajiban di antara sesama anggota serta tetap saling menghargai dan menghormati walaupun berbeda suku, gender, ras, dan sebagainya.

Sila III (Persatuan Indonesia) yang dilaksanakan dalam organisasi mahasiswa di Universitas Muhammadiyah MaKSsar juga mengandung nilai-nilai yang akan dicapai yaitu cinta tanah air dan bangsa, memajukan pergaulan demi persatuan dan kesatuan yang berBhinneka Tunggal Ika dan mewujudkan sikap bangga sebagai bangsa Indonesia.

Berdasarkan hasil penelitian, penerapanNilainilai Pancasila sila III (Persatuan Indonesia) dilaksanakan dalam berbagai cara diantaranya adanya rasa bangga menjadi bangsa Indonesia, memiliki rasa kebersamaan bersemboyan Bhinneka Tunggal Ika, dan mengutamakan kepentingan umum diatas kepentingan pribadi.

Hasil penelitian sesuai dengan nilai-nilai sila III (Persatuan Indonesia) menurut Rukiyati dkk (2013: 6) menyatakan bahwa pokok-pokok pikiran yang terkandung dalam sila Persatuan Indonesia adalah nasionalisme, cinta bangsa dan tanah air, menggalang persatuan dan kesatuan bangsa, menghilangkan penonjolan atau kekuasaan keturunan dan perbedaan warna kulit serta menumbuhkan rasa senasib dan seperjuangan.

Berdasarkan hasil penelitian dan kajian teori dapat disimpulkan bahwa penerapan Nilai-nilai Pancasila sila III (Persatuan Indonesia) dalam mencegah kenakalan remaja di SMA Negeri 1 Enrekang dilaksanakan dalam berbagai cara diantaranya adanya rasa bangga menjadi bangsa Indonesia menggalang persatuan dan kesatuan bangsa, dan mengutamakan kepentingan umum diatas kepentingan pribadi.

Makna Pancasila Sila IV (Kerakyatan yang Dipimpin oleh Hikmat dalam Permusyawaratan/Perwakilan) nilai yang terkandung dalam sila ini didasari oleh sila pertama, kedua, ketiga, dan kelima. Nilai filosofi yang terkandung di dalamnya adalah bahwa hakikat negara sebagai penjelmaandari sifat kodrat manusia sebagai makhluk Tuhan Yang Maha Esa yang bersatu yang bertujuan mewujudkan harkat dan martabat manusia dalamsuatu wilayah negara. Negara adalah dari, oleh dan untuk rakyat. Oleh karena itu rakyat merupakan asal mula kekuasaan negara.

Berdasarkan hasil penelitian, penerapan Nilai-nilai Pancasila sila IV (Kerakyatan Yang Dipimpin oleh Hikmat dalam Permusyawaratan/ Perwakilan) dalam mencegah kenakalan remaja di SMA Negeri 1 Enrekang yaitu adanya kesempatan dan kebebasan kepada semua anggota organisasi untuk menyampaikan usul atau saran yang membangun, demi kemajuan siswa tersebut dan semua siswa yang lain menanggapi dengan positif dengan mengutamakan kepentingan bersama atau kepentingan umum daripada kepentingan pribadi. Untuk itu dapat setiap masalah kenakalan remaja di SMA Negeri 1 Enrekang diselesaikan dengan cara musyawarah mufakat setelah disepakati bersama, maka harus disertai dengan adanya pertanggung jawaban.

Hasil penelitian sesuai dengan pendapat Kaelan (2010: 82), menyatakan bahwa dalam sila kerakyatan terkandung nilai demokrasi yang secara mutlak harus dilaksanakan dalam hidup bernegara. Rukiyati (2013: 62) juga menyatakan bahwa hakikat 
utama sila keempat ini adalah demokrasi dan permusyawaratan. Demokrasi dalam arti umum yaitu, pemerintahan dari rakyat, oleh rakyat, dan untuk rakyat. Permusyawaratan artinya mengusahakan putusan bersama secara bulat, baru setelah itu diadakan tindakan bersama.

Berdasarkan hasil penelitian dan kajian teori dapat disimpulkan bahwa penerapan Nilai-nilai Pancasila sila IV (Kerakyatan Yang Dipimpin oleh Hikmat dalam Permusyawaratan/Perwakilan) dalam mencegah kenakalan remaja di SMA Negeri 1 Enrekang pengambilan keputusan berdasarkan hasil keputusan bersama dan dilakukan secara musyawarah dan mufakat serta mengutamakan kepentingan umum diatas kepentingan pribadi.

Penerapan Nilai Pancasila sila $V$ (Keadilan Sosial Bagi Seluruh Rakyat Indonesia) dalam mencegah kenakalan remja di SMA Negeri 1 Enrekang diwujudkan dengan memberikan kesempatan yang sama kepada siswa dan tidak adanya sekat atau intervensi siswa di SMA Negeri 1 Enrekang.

Rukiyati dkk (2013: 63) menyatakan pokok pikiran yang perlu dipahami dalam sila kelima ini adalah kemakmuran yang merata bagi seluruh rakyat dalam arti dinamis dan meningkat, seluruh kekayaan alam dan sebagainya dipergunakan bagi kebahagiaan bersama menurut potensi masingmasing, serta melindungi yang lemah agar kelompok warga masyarakat dapat bekerja sesuai bidangnya. Nilai keadilan harus tercermin dan dilaksanakan dalam kehidupan sehari-hari.

Berdasarkan hasil penelitian dan kajian teori dapat disimpulkan bahwa penerapan Nilai-nilai Pancasila sila V (Keadilan Sosial Bagi Seluruh Rakyat Indonesia dalam mencegah kenakalan remaja adalah dengan bersikap adil kepada seluruh siswa. Upaya menerapkan nilai-nilai Pancasila dalam mencegah kenakalan remaja tentunya ada faktor yang mendukung agar tujuan tersebut tercapai. Berdasarkan hasil wawancara yang dilakukan oleh peneliti terhadap informan, terdapat beberapa hal yang mendukung nilai-nilai Pancasila yaitu adanya dukungan dari kepala sekolah, Guru, siswa serta sarana dan pra sarana yang mendukung dan adanya hubungan sosial serta pola pikir siswa.
Dukungan dari Kepala sekolah ditunjukkan dengan diperadakannya wadah dalam menerapkan nilainilai Pancasila, diperadakannya musholla dalam sekolah sebagai tempat melakukan sholat berjamaah sesuai dengan penerapan sila ke I (Ketuhanan yang Maha Esa).

Berdasarkan uraian diatas dapat disimpulkan bahwa faktor pendukung dalam menerapkan nilainilai Pancasila dalam mencegah kenakalan remaja di SMA Negeri1 Enrekang datang dari kepala sekolah, guru, dan siswa serta sarana dan pra sarana yang mendukung dan adanya hubungan sosial serta pola pikir siswa. Hasil wawancara yang peneliti lakukan terhadap kepala sekolah, guru PPKn, siswa SMA Negeri 1 Enrekang mengungkapkan beberapa hambatan dalam mencegah kenakalan remaja diantaranya Keterbatasan aloKSi waktu memberikan pembinaan dan bimbingan Guru Pendidikan kewarganegaraan dalam mengajar menggunakan aloKSi dua jam mata pelajaran, Pergaulan teman sebaya, Orangtua peserta didik tidak memenuhi panggilan dari pihak sekolah, dan sikap masa bodoh peserta didik terhadap nasihat guru.

\section{KESIMPULAN}

Berdasarkan hasil penelitian dan pembahasan di atas, maka dapat disimpulkan Penerapan Nilai-nilai Pancasila dalam mencegah kenakalan remaja di SMA Negeri 1 Enrekang dilakukan dengan mengamalkan Nilai-nilai Pancasila dalam kehidupan sehari-hari. Faktor pendukung dalam mencegah kenakalan remaja di SMA Negeri 1 Enrekang datang dari Kepala sekolah, Guru, siswa serta sarana dan pra sarana yang mendukung dan adanya hubungan sosial serta pola pikir siswa. Faktor penghambat dalam mencegah kenakalan remaja di SMA Negeri 1 Enrekang adalah Keterbatasan aloKSi waktu memberikan pembinaan dan bimbingan Guru Pendidikan kewarganegaraan dalam mengajar menggunakan alokasi dua jam mata pelajaran, Pergaulan teman sebaya, Orangtua peserta didik tidak memenuhi panggilan dari pihak sekolah, dan sikap masa bodoh peserta didik terhadap nasihat guru. 


\section{DAFTAR PUSTAKA}

[1] Asmani, Jamal Ma'mur. (2011). Buku Panduan Internalisasi Pendidikan Karakter di Sekolah. Jogjakarta: Diva Pres

[2] Abdulsyani. (1987). Sosiologi Kriminalitas. Bandung: CV Remadja karya Bakry,

[3] Noor, MS. (2001). Orientasi Filsafat Pancasila. Yogyakarta: Liberty

[4] Bungin, Burhan, (2009), Metodologi Penelitian Kuantitatfi,cet. Ke-4 Jakarta: Kencana Prenada Media Group.

[5] Elisabeth B. Hurlock. (1980). Psikologi Perkembangan. Jakarta: PT Airlangga.

[6] Kartini kartono. (1981). Gangguan-Gangguan Psikhis. Bandung: Sinar Baru.

[7] Kartini kartono. (1996). Psikologi Umum. Bandung: Mandar Maju.

[8] Kartini kartono. (2002). Kenakalan Remaja. Jakarta: PT Raja Grafindo Persada.

[9] K. Bertens. (200)2. Etika. Jakarta: PT Gramedia Pustaka Utama

[10] Ninik Widiyanti dan Pandji Anoraga. (1987). Perkembangan Kejahatan Dan Masalahnya. Jakarta: PT Pradnya Paramita.

[11] Paulus, wahana. (1993). Filsafat Pancasila. Yogyakarta: Kanisius

[12] Roucek, Joseph S dan roland L. walerren. (1984). Pengantar Sosiologi. Jakarta: Bina Aksara

[13] Solomon, Robert C. (1987). Etika Suatu Pengantar. Jakarta: Erlangga

[14] Sudarsono. (2004). Kenakalan Remaja. Jakarta :PT Rineka Cipta

[15] Sumadisuryabrata. (2001). Psikologi Kepribadian. Jakarta: PT Raja Grafindo Persada.

[16] Sunoto. (2003). Mengenal Filsafat Pancasila. Yogyakarta: Hanindita Grahawidya

[17] Suardi, S., Megawati, M., \& Kanji, H. (2018). Pendidikan Karakter di Sekolah (Studi Penyimpangan Siswa di Mts Muhammadiyah Tallo). Jurnal Etika Demokrasi Prodi PPKn Unismuh Makassar, 3(1).

[18] Suardi, S., Herdiansyah, H., Ramlan, H., \& Mutiara, I. A. (2019). Implementasi Pendidikan Karakter Melalui Mata Pelajaran Pendidikan Kewarganegaraan di SMA Jaya Negara Makassar. Jurnal Etika Demokrasi Prodi PPKn Unismuh Makassar, 4(1).

[19] Willis, Sofyan S. (2005). Remaja Dan Masalahnya, Mengupas Berbagai Bentuk Kenakalan Remaja Seperti Narkoba, Free Sex Dan Pemecahannya. Bandung: CV Alfabeta 